\title{
Helmut Kallmann: Memories and Tributes
}

\author{
by Klaus Keil, Gerald Parker, Jay Rahn, and Marlene Wehrle
}

\section{From KLAUS KeIL:}

We would like to pay tribute to Helmut Kallmann.

RISM (Répertoire international des sources musicales) has in its archive many letters from Helmut Kallmann from between 1973 and 1987 (as far as I can find from a brief search). In a notice from 1987, he writes that his engagement for RISM had started more than 30 years ago, i.e. around 1957. The main part of the Canadian RISM records provided for series B 1 and 2, A/I (over 2000) and A/II (over 200) were sent by Helmut Kallmann.

I first made his acquaintance in 1984, when he visited the RISM Zentralredaktion in Kassel on a trip through Germany, which he made in spite of the bad experiences in his youth. I met him again at the IAML conference in Ottawa in 1994.

In the last letter, dated 1987, from my predecessor Joachim Schlichte to him, Helmut Kallmann's retirement was discussed. RISM benefited greatly from his contributions.

KLAUS KEIL is Director of the RISM Zentralredaktion, Frankfurt am Main, Germany. He studied theology and musicology with Helmut Hucke, Ludwig Finscher, Hans Heinrich Eggebrecht, Winfried Kirsch and Klaus Hortschansky in Frankfurt am Main and Freiburg im Breisgau. He began working freelance with the RISM Zentralredatkion in 1982 and in 1988 he became a research associate. Since 1991, he has been the director of the RISM Zentralredaktion.

FROM GERALD PARKER:

I worked for a few years with Dr. Helmut Kallmann. I was Edward B. Moogk's successor as head of the Recorded Sound Collection in the Music Division of the National Library (NLC), of which Dr. Kallmann (or "Dr. K") as I liked to call him) was in charge; before that I was head of the Music Cataloguing Section in the Cataloguing Branch of the NLC and I had had many occasions then, also, to work with Ed Moogk and Dr. Kallmann. As many have observed, Dr. K was a quiet and somewhat unassuming, retiring sort of man. 
Dr. K was, however, quite (and rightly) proud of his work and of being such an absolute authority about Canadian classical and folk music, something which was incontestable. On Canadian popular music of then recent decades, however, Dr. K was only very generally informed and could be comically confused about it at times; I'll never forget his totally inapt description of Hagood Hardy's music! Because the work of collecting and documenting recorded sound in Canada so largely centred on popular music and jazz, and, for that matter, even on non-musical recordings, Dr. K took less direct interest in sound recordings than in Canadian music manuscripts, printed music, and books. I appreciated this, however, since he allowed such great latitude to the work that I (and Ed Moogk before me) did to preserve Canada's heritage of recorded sound.

I almost had forgotten how meticulous Dr. K was about his own and others' writing; he scrutinized all divisional correspondence very carefully, assigned his own filing numbers (a well-devised system) to each letter, and assured that any letters sent out in the division's name were accurate and well composed and also retrievable with reasonable ease, making the correspondence files useful as documentation of Canadian "musicalia". I had less interpersonal contact with Dr. K, but, like all of the staff of the Library and of the Encyclopedia of Music in Canada, I held him in great esteem.

Gerald PARKer is a native of California, educated at the University of Massachusetts in Boston (B.A. in Music) and at Kent State University (M.L.S.). He served in professional positions at the New England Conservatory and at the Boston Public Library before taking up his first Canadian music library post at the University of Western Ontario. He then worked at the National Library of Canada and at the Université du Québec à Montréal. Upon retirement he moved to Rouyn-Noranda, QC, where he now lives. He has published widely in English and French, including in numerous prestigious American, Canadian, and British periodicals.

\section{FROM JAY RAHN:}

Toward the end of the fall semester of John Beckwith's 1968-69 course on North American music at the University of Toronto's Faculty of Music, I decided to write an essay on the first Canadian English-language music publication, Stephen Humbert's Union Harmony (1801). Unknown to me, John contacted Helmut, who sent me a copy of the book and I spent the Christmas holidays analyzing and researching its author and contents. The essay later became the basis for my entries on Humbert and the Union Harmony in the first edition of the EMC. Most important, the contact with a real primary source fired my enthusiasm for basic research. 
JaY RaHN is Professor (Music) at York University. Among his publications on Canadian music are a life-and-works book on LaRena Clark (with Edith Fowke) as well as several analytical and historical studies of English- and French-language traditional songs of Canada.

FROM MARLENE WEHRLE:

I would like to share a couple of reminiscences that show Helmut's lighter side. In 1971, I had a summer job in the Music Division at the National Library, just one year after Helmut's appointment as Division Chief. On arriving at the office one day he told his staff that, while listening to CBC Radio that morning, he had been shocked to hear what he considered a less-than-beautiful recording of a singer. He decided that she must have been famous, since nothing else could justify the broadcast. He then gave a brief and quite comical imitation of what he had heard. At that moment a colleague from a neighbouring division walked by, giving Helmut a startled look. Without missing a beat, Helmut explained: "But it wasn't me, it was Kathleen Ferrier!"

One day shortly before Helmut retired in 1987, I was with him in his office that overlooked Wellington Street when, glancing out the window at the traffic below, he said "There goes my birthday bus!" "Birthday bus?" I enquired, while wondering if he was starting to lose his marbles. He explained that it was bus number 7822, which was the date of his birthday: 7 August 1922. He went on to say that he spotted it regularly, usually on a few specific routes, and had even ridden on it a few times. Of course, his attention to detail extended far beyond the world of music. Many years after leaving Berlin, he was able to provide his native city with details about streetcar routes that were in effect when he had lived there in his youth. It was only natural that he would note the numbers on Ottawa city buses, with a special fondness for No. 7822.

MARLENE WEHRLE worked as a librarian at the National Library/Library and Archives Canada for over 30 years, in the Legal Deposit Office and the Music Division. At the time of her retirement in 2009, she was Head of the Printed Music Collection. She enjoys reading and needlepoint, sings in the Ottawa Choral Society, and volunteers with a therapeutic riding program. 